\title{
Tree-ring based reconstruction of snow avalanche frequency in Şureanu Mountains (Southern Carpathians, Romania)
}

\author{
Olimpiu Traian Pop, Flaviu Meseșan, Ionela-Georgiana Gavrilă, Cosmin Timofte \\ Laboratory of Dendrochronology \\ Faculty of Geography, Babeș-Bolyai University \\ Cluj-Napoca, Romania
}

\begin{abstract}
Snow avalanches represent a widespread phenomenon in the Carpathians, damaging forests, properties, infrastructures and causing fatalities. In remote mountain areas, historical records of snow avalanche activity are commonly lacking. Trees repeatedly disturbed by snow avalanches record evidence of past events in their annual rings. The main purpose of the present study was to analyze tree-ring records in order to reconstruct frequency and spatial extent of past avalanche activity along a path located on the southern slope of Şureanu Peak (2059 m a.s.l.). Samples collected from 54 Norway spruce trees (Picea abies (L.) Karst.), heavily disturbed by snow avalanches, have been analyzed and their tree-growth anomalies identified (e.g. scars, callus tissues, the onset sequences of tangential rows of traumatic resin ducts, compression wood, growth suppression and release sequences). The growth anomalies found within the tree rings served to date past avalanche events, back to late 19th century. Finally, the minimum frequency of snow avalanches has been determined. In the studied area, dendrogeomorphic methods provide the most consistent avalanche event chronology and can further contribute to an accurate avalanche hazard zonation.
\end{abstract}

Keywords - snow avalanches; tree rings; Norway spruces; event frequency; Şureanu Mountains (Romania)

\section{INTRODUCTION}

Snow avalanches affect various mountain areas in the world and represent one of the rapid debris transfer mechanisms in these environments. Avalanche activity repeatedly damages inhabited areas, infrastructures, forests and causes fatalities. In the avalanche prone areas, understanding the process frequency and magnitude is crucial for a precise hazard zonation. High-resolution hazard mapping is needed to reduce the avalanche-related risk, particularly in mountain areas with human activity (e.g. the winter tourism resorts).

In remote mountain areas, hazard zonation is commonly hampered due to a lack of historical records regarding the past snow avalanche activity. This is the case for the central part of Şureanu Mountains (Southern Carpathians, Romania), where the snow avalanche history is undocumented by archival records. Here, the coniferous forests have repeatedly experienced destructive snow avalanches in the past, as attested by the presence of damaged trees along the paths. It has been already proven that dendrogeomorphology offers the possibility to accurately date and determine the spatial extent of past snow avalanches occurring across the forested slopes. So far, in Şureanu Mts., dendrogeomorphic studies have never been applied to exploit the valuable information stored within tree-ring archives, despite the great potential that trees offer in this area for such studies. Here, multiple avalanche paths are located next to the ski area. The aim of this study was to use various dendroecological indicators in order to reconstruct snow avalanche frequency along one of the path in Şureanu Mts.

\section{STUDY AREA}

Şureanu Mts. belong to the Southern Carpathians Range (Fig. 1). In their central area, the maximum altitude reaches 2059 m. a.s.l. on the Şureanu Peak. Below the main peak, multiple avalanche paths have their release areas located on steep slopes $\left(>25^{\circ}\right)$, and extend downward across coniferous forests mainly composed of Norway spruce trees (Picea abies (L.) Karst.). The investigated Auşelu avalanche path is located on the southern slope below Şureanu Peak, extending downward from the subalpine shrub area at $2050 \mathrm{~m}$ a.s.l and crossing the forest. It reaches the gentle slopes at about $1600 \mathrm{~m}$. a.s.l., in the confluence area with another avalanche path from the right side.

\section{METHODS}

\section{A. Field sampling and laboratory analyses}

After the identification of avalanche path on the orthophotoplans and in the field, disturbed trees growing within the path have been selected for sampling (Fig. 2). A total number of 54 P. abies trees have been sampled, their spatial position being determined using a GPS device. Sample collection includes increment cores extracted with a Pressler borer from 36 trees (minimum 2 cores per tree) and stem discs cut from 18 fallen and/or topped trees. 


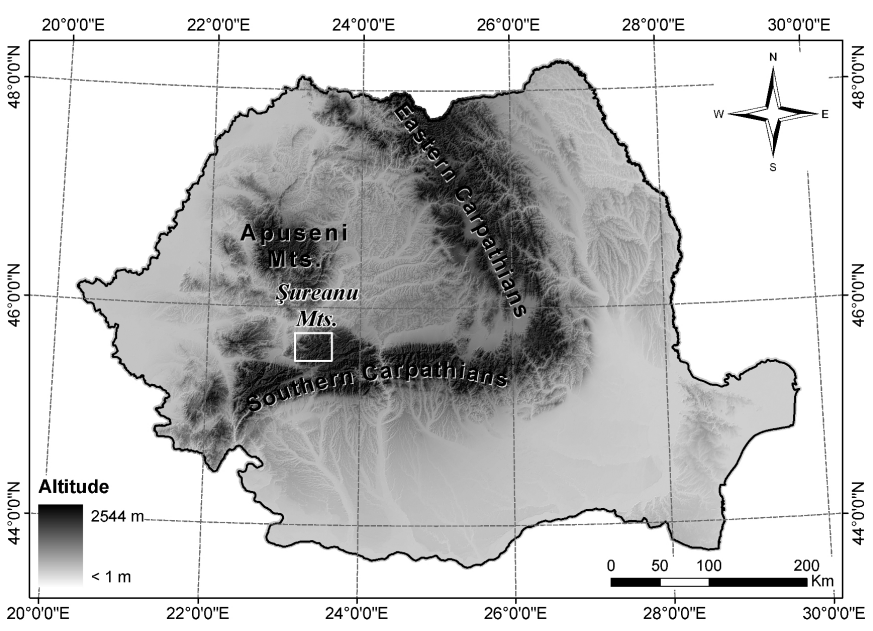

Fig. 1. Map location of Șureanu Mountains in Romania.

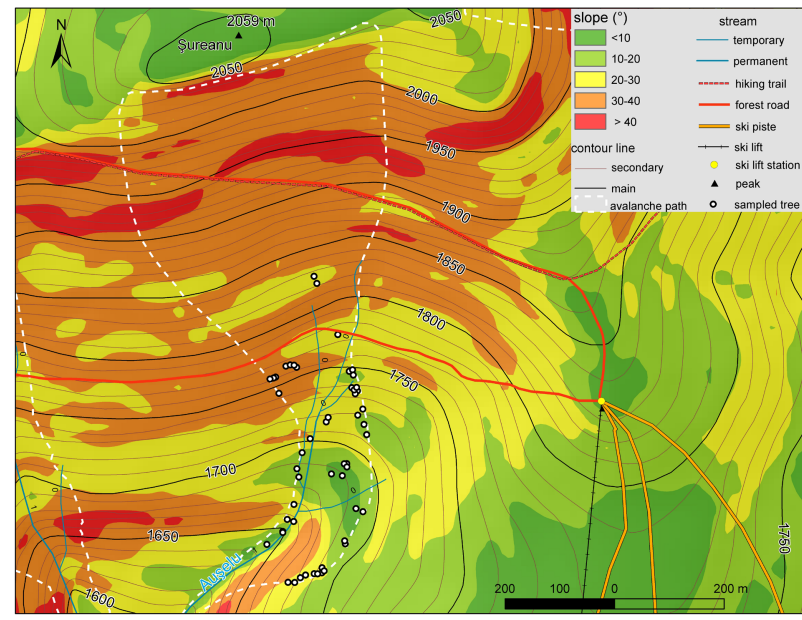

Fig. 2. Location of the Auşelu avalanche path and spatial distribution of the sampled trees.

In laboratory, all samples (cores and stem discs) have been prepared for analysis following the standard dendrochronological procedures [1]. After the air-drying, sanding and age determination by ring counting, ring widths have been measured to the nearest $0.01 \mathrm{~mm}$ using a digital LINTAB positioning table connected to a Leica stereomicroscope and TSAP-Win ${ }^{\mathrm{TM}}$ Professional 0.22 software [2]. To detect dating errors (i.e. missing or false rings), tree-ring series have been cross-dated. The quality of the cross-dating was evaluated statistically using the program COFECHA [3] and visually by the graphical function of the program TSAP-Win. Reference chronology obtained previously from undisturbed trees growing at several tens of km distance in Parang Mts. [4] served for cross-dating with growth chronologies of disturbed trees, to identify and correct the missing/false rings. Samples from damaged trees have been analyzed, in order to detect growth anomalies related to mechanical stress caused by snow avalanches. Growth disturbances included mainly the onset sequences of compression wood, tangential rows of traumatic resin ducts accompanied by callus tissue partly covering the margins of the scars, as well as the growth suppression sequences (GS) other than those caused by climatic factors [5].

\section{B. Avalanche event determination}

Event reconstruction was based on the type, intensity and number of growth disturbances (GDs) detected within growth rings. Scars (SC) in association with callus tissue (CT) have been identified mainly within cross-sections. The onset sequences of traumatic resin ducts (TRD), compression wood (CW) and growth suppressions (GS) identified within both cores and cross-sections have been separated by intensity classes (low, medium and high intensity), according to the classification of [6]. An avalanche activity index $\left(I_{t}\right)$ has been then calculated using the formula proposed by [7]:

$$
I_{t}=\left(\sum_{i}^{n}={ }_{1} R_{t} / \sum i^{n}={ }_{1} A_{t}\right) \times 100
$$

- $\quad R$ represents a tree that presents at least one growth reaction in a specific year $t$;

- $\quad A$ represents the tree alive in that year $t$.

The following two criteria have been used to reconstruct a distinct avalanche event:

(1) the presence of clear GD, such as SC, CT and TRD or CW reactions with high and medium intensity found in minimum three disturbed trees form the ten trees alive in that year;

(2) the calculated avalanche activity index $\left(I_{t}\right)$ having a minimum threshold value of $10 \%$

\section{RESULTS}

\section{A. Avalanche frequency reconstructed}

The oldest sampled tree's first growth ring is dated back in 1877, while the youngest sampled tree's first ring is from 2002. Taking into account the number, type, intensity of growth anomalies and the calculated values of $I_{t}>10 \%$, it is possible to reconstruct a number of 10 past avalanche events spanning the 1877 - 2016 period (Fig. 3). It represents a minimum number of events that dendrogeomorphic methods allowed to be reconstructed. Other possible event years could also be determined, but the small number and weak intensity of growth disturbances in these years doesn't allow us to reconstruct with high confidence a distinct event. The event year 2000 defined by the largest number of disturbed trees showing growth reactions (40 trees), as well as the highest values of $I_{t}(78 \%)$ can be considered as one of the largest avalanche event which occurred along the investigated avalanche path during the reconstructed period.

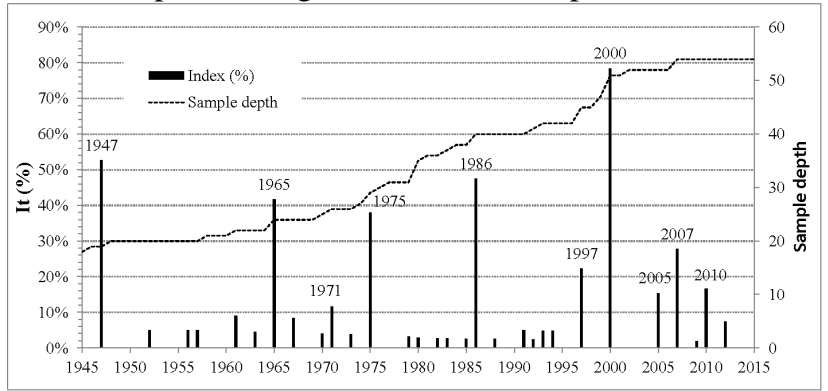

Fig. 3. Event frequency histogram reconstructed with tree rings for the Aușelu avalanche path. 


\section{CONCLUSIONS}

The results of the present dendrogeomorphic study serve to reconstruct the minimum frequency of snow avalanches along the Auşelu avalanche path. Tree ring records provide clear evidence of 10 events that occurred in the past between 1887 and 2016. Dendrogeomorphic methods can contribute significantly to snow-avalanche hazard zonation, helping also in planning decisions in the studied area. Further analyses on additional trees sampled are necessary, in order to identify supplementary events and to complete the avalanche chronology of the investigated path. More investigations extended also to other avalanche paths in the area should offer a better understanding of the snow avalanche patterns at a regional scale.

\section{REFERENCES}

[1] O.U. Bräker, "Measuring and data processing in tree-ring research - a methodological introduction”, Dendrochronologia, vol. 20, pp. 203-216, 2002.

[2] RINNTECH, 2017. TSAP-Win ${ }^{\mathrm{TM}}$-Software for tree-ring measurement, analysis and presentation. http://www.rinntech.com.

[3] R. L. Holmes, "Computer-assisted quality control in tree-ring dating and measurement”, Tree-ring bulletin, vol. 43, no. 1, pp. 6978, 1983.

[4] O.T. Pop, I.G. Gavrilă, Gh. Roșian, F. Meseşan, A. Decaulne, H.H Iulian, and T. Anghel, “A century-long snow avalanche chronology reconstructed from tree rings in Parang Mountains (Southern Carpathians, Romania)”, Quaternary International, vol. 415, pp. 430-440, 2016.

[5] F.H. Schweingruber, Tree Rings and Environment. Dendroecology. Paul Haupt, Bern, Switzerland, 1996.

[6] M. Stoffel and C. Corona, "Dendroecological dating of geomorphic disturbance in trees”, Tree-Ring Research, vol. 70, no. 1, 3-20, 2014.

[7] J.F. Shroder, "Dendrogeomorphological analysis of mass movement, Table Cliff Plateau, Utah”, Quaternary Research, vol. 9, pp. 168-185, 1978. 